\title{
Co-Production: Fostering Greater Inclusion or Reproducing Existing Exclusion? An analysis of co-commissioning and resident participation on a South London Housing Estate
}

\author{
Dr. James Alexander \\ j.alexander@londonmet.ac.uk \\ London Metropolitan University
}

\section{To cite this item:}

Alexander, J., 2021. Co-production: fostering greater inclusion or reproducing existing exclusion? An analysis of co-commissioning and resident participation on a South London housing estate. SN Social Sciences 1, 56. https://doi.org/10.1007/s43545-021-00058-0

\begin{abstract}
In many neoliberal economies, co-production is an increasingly popular way of generating public value, empowering citizens, and innovating public service delivery, and cuts to public sector budgets have seen it becoming more important as cash strapped public bodies strip back their services. However, its effectiveness as a means of inclusive engagement is unclear. This paper uses Bourdieu's theory of practice to explore ethnographic data relating to the collaborative commissioning of a youth project on a South London housing estate and understand how effective the activities were at empowering people to take action. The study shows that although co-production has the potential to increase local involvement; the habitus of those with greater political, economic, and professional capital shaped the social space in which participation takes place. This habitus shaped how people should engage, causing some to disengage, limiting what outcomes were possible. Co-productive practices, such as the co-commissioning discussed in this paper, contain the promise of greater participation and empowerment. However, a lack of understanding of the power dynamics between those involved means the processes can be hierarchical and restricting, rather than increasing the participation of those whom such initiatives are meant to empower.
\end{abstract}

Keywords: Neighbourhood; Bourdieu; Ethnography, Youth Crime, Co-production, Exclusion 


\section{Introduction}

Co-production, an interactive collaboration between citizens and professionals, which can include the coplanning, co-prioritising, co-design, co-commissioning, and co-delivery of services (Alford 2013; Eijk and Steen 2016; Loeffler and Bovaird, 2019; Thijssen and Van Dooren 2015), has become a buzz word in the provision of local non-statutory services, offering the opportunity for greater user involvement, delivery diversity, and financial efficiencies in an age of budgetary constraints.

This paper draws on ethnographic data which explores the co-commissioning of a youth violence reduction project on an estate chosen as the test area for a local authority's new co-operative delivery model. In referring to the cocommissioning process, as it relates to the data, the author will use the term co-production or co-commissioning, whilst recognising that co-commissioning is only one facet of co-production. The analysis uses Bourdieu's theory of practice to explore how social field and habitus shaped the co-production that took place. The analysis shows that something which was meant to empower local people by devolving power away from the local authority, simply handed it over to a local organisation, mirroring existing power structures, at the expense of residents' wishes and involvement. Ultimately, an initiative that was meant to increase participation in local service delivery led once committed residents to feel unvalued, with some disengaging completely from the process.

\section{Professionalisation and Co-production}

Co-production refers to an interactive collaboration between citizens and professionals, which can include the coplanning, co-prioritising, co-design, co-commissioning, and co-delivery of services (Alford 2013; Eijk and Steen 2016; Loeffler and Bovaird, 2019; Thijssen and Van Dooren 2015). The process places the codified expertise of professionals alongside the specific situational expertise of the layperson (as outlined in Kotzee (2014)), to develop collective shared goals to address local concerns (Alford and Yates, 2016; Booth 2019; Bovaird et al., 2015a, Crompton; 2018; Flinders and Wood, 2018; Pestoff 2009; Vanleene, et al., 2018). This positioning of professionals alongside lay people democratises services and empowers citizens to move from passive recipients to co-producers of interventions (Brunton-Smith and Bullock, 2018; Crompton, 2018; Pestoff 2009), which had previously been the sole domain of professionals (Fledderus et al., 2015; Innes et al., 2018; Vanleene, et al., 2018). Co-production should go beyond seeking greater participation, without a consummate redistribution of power, and result in the sharing or delegation of power akin to the upper rungs of Karner's (2008) ladder of citizen participation. 
The advent of 'austerity Britain', local authority budget cuts, and the powers afforded to local organisations in the Localism Act, (2011), saw many councils in the UK turning to co-production, due to its ability to empower residents to deliver services in a cost effective way (McQuaid 2010; Pestoff 2009; Osborne et al. 2016; van Eijk 2018), and provide public value through providing services in new and innovative ways (Alford, 2009; Bovaird and Loeffler, 2012).

People's willingness to engage in such initiatives is often dependent on their perception of how influential their involvement will be (Bovaird and Loeffler, 2012; Bovaird, et al., 2015b; Thijssen and Van Dooren 2015; van Eijk and Steen 2016), as well as their perception of other's involvement (van Eijk, 2018). However, within deprived neighbourhoods, nonengagement is often a strategy for coping with situations of multiple disadvantage (Offer, 2012), as well as a consequence of a belief that engagement will offer little personal benefit (Mathers et al., 2008). Therefore, the most deprived citizens are often underrepresented in processes aimed at empowering them (Crompton, 2018; Docherty et al., 2001; Galuszka, 2018). As such, the first aim within co-productive processes is often to address issues representation (Tonkens and Verhoeven, 2018). Bottom up activities that promote bridging capital, supported by professional mediation and guidance, have proved the most effective in engaging those previously disinterested (Tonkens and Verhoeven, 2018; Vanleene et al., 2019). The way in which professionals facilitate initiatives, therefore, significantly influences how collaborative, inclusive, and coproductive they become.

However, co-producers bring their own frame of reference, which can result in some co-producers being considered less capable of participating fully or delivering the type of public services decided upon (Crompton, 2018; Jakobsen and Andersen 2013; Thijssen and Van Dooren 2015). This is especially true when professionals frame the collaborative process within their own existing delivery model (Crompton, 2018), leading to a disconnect between the inclusive co-production narrative and what people experience. Co-production can, therefore, disempower those who are unsure of how to express themselves within, often professionally oriented, co-productive spaces (Fung, 2015). Although the term professionalism is often loosely used (James 2016; Moskovskaia 2012), it still connotes an understanding of standardised education or training, which ensures a set level of competency (Brubaker and Keegan 2018; James 2016; Moskovskaia 2012). This can lead to the belief that only those viewed as professionals can fulfill certain roles, excluding apparent nonprofessionals (Ashcraft, et al., 2012; Brubaker and Keegan 2018; Evetts 2006, 2011a, 2013; James 2016; Lyons 2011, Noordegraaf 2011; Waring and Waring 2009). 
Including users as co-producers can increase the uncertainty regarding the quality and the effectiveness of collaboratively developed services (Fledderus et al., 2015), resulting in some public bodies' reluctance to cede control to potentially unsuitable community groups, choosing instead to invest authority into other likeminded professionals in order to provide as much certainty as possible (Fledderus et al., 2015; Innes et al 2019; Pestoff and Brandsen, 2010). Consequently, there can be concerns over what meaningful engagement should look like, resulting in a perceived trade off between delivery standards and the level of participation possible.

Service users can become seen simply as assets to the process, resulting in tokenistic marginal involvement (Crompton, 2018; Leyshon, et al., 2018; McQuaid, 2010) rather than equal partners (Crompton, 2018). Therefore, although co-production can create a more collective creative space, unequal power dynamics can mean dominant participants reinforce existing exclusivist and disenfranchising power structures and processes, leading to participants withdrawing (Crompton, 2018) and co-production narratives being seen simply as nice rhetoric (Flinders and Wood, 2018). Co-production can, therefore, be a paradox. On the one hand, it is a democratic process that aims to foster greater participation, (Booth, 2019; Farr, 2017; Innes et al., 2018), on the other, projects labelled co-productive can reinforce unequal disenfranchising power dynamics (McQuaid 2010). To combat this, the initial emphasis of co-productive partnerships is often on professionalising the actions of perceived amateurs, with the view of helping them engaging effectively (Fledderus, et al., 2015; Pestoff and Brandsen, 2010). However, professionals need to equally reflect on their own practices and move past approaches that reproduce unhelpful dichotic service provider, service user power structures. (Booth 2019; Farr 2018).

\section{Theory of Practice Framework}

The project used Bourdieu's theory of practice as a framework to help shed light on how the social spaces of individuals and groups influence their perception of what should happen and how they viewed others. After many years of minimal facilitation by the council, resulting in the estate's Residents Committee developing their own informal approach to addressing estate based issues, a number of intersecting events and policy decisions (outlined below) meant that relatively suddenly the estate was a hive of local authority activity. This change was theorized through understanding different ways of working as distinct social fields, each with its own habitus and capital, guiding those operating within them. The account below discusses the power dynamics that emerged as people from these two social fields tried to plan what should be done to support local young people. 
For Bourdieu (1990), social activity takes place in fields, structures within the social world, outside of the thoughts and motivations of individuals, which constrain action by setting the rules and logic for engagement in a reflexive relationship with habitus and capital (Grenfell 2014; Steinmetz 2011).

Habitus is a person's preferences and dispositions which is acquired over time, whilst being shaped by immediate social and physical relations within neighbourhoods, workplaces, and friendship and kinship networks. Long term submersion in the field produces a 'feel for the game', a shared, unquestioned intuition that causes people to misrecognise the rules and procedures of a field as a 'natural' convention that 'goes without saying' (Bottero 2010; Decoteau 2015; Oliver and O'Reilly 2010; Steinmetz 2011). The wrong habitus in the wrong environment, such as having the wrong accent or using informal speech within a formal setting, will result in negative consequences (Reeves 2014).

Habitus usually follows along class lines and gives the holder a sense of group identity (Bourdieu 1984; Bourdieu 1990). Those living in poor neighbourhoods can find their habitus shaped by their exclusion from certain experiences. As a result, the value system, habitus, and practices of those living on estates are often considered of little value elsewhere (Mckenzie 2012, 2015). This status can be internalised, with those from disadvantaged backgrounds accepting this inferior position as natural (Mckenzie 2012, Pemberton et al., 2016) and a source of shame (Hickman, 2018).

Within Bourdieu's work, there are four main forms of capital: economic capital, financial resources; cultural capital, a person's awareness and embodiment of particular cultural traits; social capital, the connections and relationships that someone can draw upon; and symbolic capital, the representation of other forms of capital, such as a job title representing someone's social and economic capital. For Bourdieu, people possess capital in different amounts, stacking the deck in favour of some more than others (Grenfell 2014; Oliver and O’Reilly 2010; Swartz 1997).

Dominance is maintained symbolically with symbolic capital such as titles, educational qualifications, and particular affiliations giving people the social authority to define particular perceptions and actions as legitimate and others illegitimate (Bourdieu and Wacquant 2013).

One such symbolic form of domination for Bourdieu (1972) can be found in policies to professionalise practices that progress certain interests by making them appear objective and intrinsically legitimate. As such, particular groups are recognised as having more right to particular positions of authority and influence than others. Within 
deprived neighbourhoods, this form of symbolic power helps local authorities take positions of superiority and impose their systems on to residents, who are perceived, and perceive themselves, as inferior (Mckenzie, 2015).

\section{Research Setting and Methodology}

The research took place on St Mary's Estate in South London. The last local authority estate survey showed that just over $48 \%$ of the 3000 residents have lived on the estate for more than 10 years, $27 \%$ less than five years, and $10 \%$ less than a year, and $57 \%$ of the residents are female. In terms of ethnicity, $27 \%$ are of Black African origin, $18 \%$ are of Black Caribbean origin, $18 \%$ are White British, $7 \%$ were Portuguese, and $6 \%$ of other White backgrounds.

One of the starkest observations from anyone who tries to do anything locally is that there are only a dozen or so residents who are actively involved in community activities, with only 10 to 15 regularly coming to meetings on the estate. From this group, only a handful or so actively participated in organising activities. This contrasts with the accounts older residents gave of legal advice surgeries, parent and toddler groups, youth clubs, elderly lunches and dominoes competitions all previously run by residents.

All but two of the active residents are women and mainly from a mix of Black Caribbean and White British backgrounds. The ethnic demographics have changed in recent years and those leading the activities largely represent the old guard. For example, Dorothy, a retired social worker from the Caribbean, moved onto the estate in the 1980s, used to run a summer playscheme and organize a legal advice clinic, still runs an over 50s club, and informally supported many of the estate's young people. Elizabeth, who moved down from Birmingham in the 1980s had been a fixer type character, finding whatever people needed from drugs, advice, childcare and even helping to return stolen goods. Latterly she worked in the background, helping to organise resident led projects and securing small pots of funding. Second and third generation Jamaicans, Charis, in her 40s, and daughter, Miche, had been supported by both Dorothy and Elizabeth to run several young people's projects. Although the number of those involved were small, their commitment was staggering, and it was hard to get anything done without their support.

The residents engaged in the social and political life of the estate had, for many years, been responsible for most of what was organised on the estate. Generally, by the time something made it to the Residents Committee's monthly meetings, it had been discussed and agreed upon informally, with the meetings simply acting to formalise decisions. The resident participation officer and the area housing manager largely just rubber stamped the 
residents' plans, trusting the residents to get on with things. However, times were changing, the estate had been chosen as the test area for the new local authority co-operative approach (discussed below), which, alongside a change in area housing manager and participation offer, resulted in a shift in local dynamics. For example, under the old management, the residents had been told they could have a 10 year lease on a disused community hall once it was refurbished, however the new management was adamant that a professional organisation should take on its management.

This was an opportunistic Complete Member Research project (Adler and Adler 1987; Anderson 2006; Charmaz 2004; Denshire 2014) based on 'insider research' (Bucerius 2013; Hammersley and Atkinson, 2010), with my involvement in the field preceding the study. I had lived in the area for several years, was a trustee and coach of a local football project, member of the Residents' Committee, and had been involved in resident activities to support local young people. As my Ph.D. progressed, I took on additional roles, including becoming secretary of the Residents' Committee, allowing me greater access to information. I also ran a youth construction training programme, supported by the council, which helped give me greater access to local officials. Much of the ethnographic data came from my time administering one of the roles I played on the estate, or through the related informal chats and meetings that made carrying out these roles possible.

As an Analytic Auto-Ethnographer, I remained coupled, rather than detached from the research (Struthers, 2014), prioritizing the narrative that was unfolding (Ellis and Bochner, 2006) whilst ensuring reflexivity by focusing on the way the subject matter related to theory rather than producing evocative descriptions (Anderson 2007; Charmaz 2004).

Although insider status allowed me to gain a richness of understanding (Dywer and Buckle, 2009), I had to balance the benefits of this closeness and the potential bias my position may lead to. Therefore, I used various sources to cross verify my understanding of events and accounts (Dhattiwala, 2017; Kelly, 2014), including asking respondents in interviews their views of incidents I had already collected data on and drawing on documented accounts from organisations operating on the estate.

The study concentrated on the official public life of the neighbourhood, focusing on the activities of the Residents' Committee, the local authority, and organisations commissioned to work in the area. The study aimed to uncover the position of the marginalised within various power and political structures (Molland 2013), without contributing to the current system of domination (Fortun 2012), by helping give the residents a voice. The aim 
was to understand the causal relational chains of action that created meaning and decided what was defined as possible (Machamer, et al., 2000; Tavory and Timmermans, 2013) that were causing the residents to feel disenfranchised rather than empowered.

Therefore, I positioned myself to research through collaboration (Amit, 2004; Eglinton, 2013) with continual reciprocity and mutual learning between myself and the respondents (Eglinton, 2013), who helped identify what areas of study to focus on, as well as often informally telling me to "Stick that in your Ph.D.". I made a conscious decision to write myself into the project as a respondent (Bourdieu, 1992; Blackman, 2007; Denzin and Lincoln, 2018), placing my voice alongside others in keeping with the collaborative approach to the research (Denshire and Sturt, 2014; Geertz, 2007; Gobo, 2018).

Alongside ethnographic and interview data, the account below also includes analysis of documents that formed part of the co-operative commissioning process. The wider Ph.D. research included data from interviews with 17 adult residents or ex-residents, 19 young people, and five staff members from the council or organisations working on the estate. Theoretical sampling (Emmel 2013), where data was collected and analysed incrementally, the results of which helping to identify whom to include as future respondents (Corbin and Strauss 2008), allowed the project to stay focused, identifying interview respondents who would have information on theoretical concepts or themes that the initial coding identified as important.

The name of the estate, the organisations represented and the people involved have been anonymised, with pseudonyms and composites used to obscure the participant's identities.

\section{Youth Support on St Mary's Estate}

In the summer of 2006, Charis, a single mother didn't want her youngest daughter to go the way of Miche, her elder, in making a name for herself, so asked Elizabeth, who lived in a flat below, what they could do to calm the young people down over the summer.

Throughout that summer Charis and [author], supported in the background by Elizabeth, spent their evenings supervising children and young people as they played on the estate. By the autumn the three residents, without support from the local authority, ran the only youth provision on the estate, a twice weekly youth project in Our Place, the local community space. Activities ranged from; homework support, arts and crafts, music sessions and a Friday movie night using a borrowed projector and illegally downloaded movies. Soon Charis and [author] 
became the go to people if a resident or the local neighbourhood police were worried about the actions of a local young person, or if a young person needed support. Charis comments:

'It worked because we knew them all if there was any trouble we would go round their parent's house and people used to call us to check on their children.'

(Interview with Charis 13.6.13)

The project stopped in September 2009 when, Tom, a 15 year old boy was shot at while on his way to the club, with police advising against having activities that congregated young people in one place. Tom was stabbed to death outside his school the following June, which proved a turning point for the estate, with the tragedy causing the local authority to take action.

In February 2011, the council commissioned two borough wide gang intervention programmes to run from Our Place for three months. The Residents Committee objected to bringing outside young people into the area, however the plan had widespread council support and so went ahead. This was the start of the end of resident involvement in formal youth support with no residents invited to help with the interventions. When these projects ended, the young people hanging out on the estate had doubled from around 15 to 30, with the additional numbers having no intrinsic link outside of attending the specialist activities. Seeing the need to continue some form of provision, the council moved two of their youth workers onto the estate to run Friday night sessions.

One evening in June 2011, Kwaku, a 17 year old who lived above Our Place, was shot dead outside his block after hanging out in the building. This incident intensified both the Residents Committees' and the council's desire to find a more permanent and effective solution.

\section{A New Interest in the Estate and New Ways of Working}

This happened as the impacts of the austerity budget were taking effect, to which the local authority responded by becoming a co-operative council, emphasizing empowering local people to fill the void left by the shrinking budgets. The co-operative approach was a result of the council's co-operative commission document which stated:

\footnotetext{
"A significant body of evidence shows that in a number of cases community-led or community-run organisations can provide more responsive services that lead to better outcomes"
}

(Taken from the Local Authority’s Co-operative Commissioning Report, 2011) 
However, it also stated that there was a need for:

"an assessment of which organisations are best placed to meet local need and deliver the improvements citizens and staff wish to see in a local area... This framework would be called the Cooperative Council Safeguarding Framework."

(Taken from the Local Authority’s Co-operative Commissioning Report, 2011)

The commission resulted in a Co-operative Council Constitution, which focused on moving away from 'doing to' towards a 'doing with' approach to public services based on mutualism and co-operation. One of the core principles of this approach would be:

"Public services planned together and delivered through a variety of organisations, which will improve outcomes, empower citizens and users, and strengthen civil society: staff will play a vital role in providing expertise and experience and we need to align this with citizens working as equal partners."

(Taken from the Local Authority’s Co-operative Council Constitution, 2013)

What this co-operative approach meant in practice was not clear. However, the rhetoric was around new ways of working and seeing local people as partners in the co-production of services. Over the course of six months, the council commissioned several projects on the estate run by outside organisations, including an asset mapping and project development exercise and the building of a polytunnel to increase resident participation and ownership. Yet, despite the co-productive labeling, the projects failed to engage anyone new.

The lack of clarity of what the council's new approach meant was expressed by the deputy director for youth services, during the initial phase of the change, who commented:

"We have to deliver in a co-productive manner, whatever that means... I am not sure that anyone at the council knows what this means or is fully supportive of the idea, but it's what has been decided so we have to do it..."

(Field note journal 08/02/12)

This lack of clarity over what co-production meant had ramifications for what was commissioned and how residents could engage. Malcolm Howard, the council's resident participation manager, had a clearer idea of the co-operative approach: 
"It is about trying as many different things and seeing what works, we need to be a bit more acknowledging that it is not one size fits all. To force a particular mode across the borough wouldn't work"

(Interview with Malcolm Howard 25/11/13)

Malcolm Howard explained the reason for the new initiatives' initial focus on the estate:

The estate is getting considerable attention and the leader of the council wants something done; the MP is putting pressure on the cabinet to find answers, and we don't have the money like we once did. The Residents Committee has some great people, but they are struggling, so we have to find a way to get more people involved.

(Interview with Malcolm Howard 25/11/13)

The backbone of this new collaborative approach were local council networks made up of local businesses, charities, resident groups, and individual residents, which were tasked to take ownership and co-produce projects to address identified local issues.

One of the first projects for the St Mary's network was the co-commissioning of youth activities on St Mary's Estate. The kick-off meeting was attended by Darren, the Deputy Director for Youth Services, several local councillors, and commissioning officers, [author], Elizabeth, Dorothy, and Charis, representing the estate, three staff members from Saplings, a local council funded adult education charity and a few residents from nearby estates.

At the meeting, Darren explained that the council would invest $£ 25,000$ in youth provision, circulating a document outlining their aims and objectives, which stated:

\section{Background}

- $\quad$ The youth service has delivered targeted programmes for St Mary's Estate between May 2010 and September 2011 but is not something the youth service has the capacity to deliver in the long term.

- $\quad$ These sessions tended to attract young people who police intelligence shows are involved in youth crime and whom the police believe to be members of a gang. 
- More recently St Mary's Estate residents' committee approached the youth service with a request to 'quality assure' some volunteers they had identified in order for them to open and run the Community Flat but this is not something the youth service is able to do.

\section{Proposal}

- St Mary's is a priority for the Police and Community Safety.

- $\quad$ The youth service has put aside $£ 25 K$ for youth activities but this funding will need to target the identified client group and will require an acceptance that there is a youth crime/gang issue in the area.

- It is proposed that a meeting is held in the first instance with St Mary's Forum and Council partners.

- $\quad$ That this meeting looks at:

o What is in place and what the community might want in terms of universal and targeted services

o What venues can be used, for what activities and for what age/target group (this needs to build on the community audit completed/is being completed by Saplings).

(taken and abridged from the local authority's St Mary's Youth Commissioning plan)

During the discussion, there were some objections regarding some background points, namely, there was no mention of the residents' support for young people and the timeline appeared incorrect. Elizabeth also wanted the 'quality assure' point clarified stating:

"This is not exactly true. We really wanted someone with a recognised qualification to let others know we were doing the right thing."

(Fieldnote Journal 26/10/11)

The Residents Committee felt that they should be managing, if not delivering, any project, and with the increased political attention had reached out to get confirmation from someone with professional status that they were doing 
the right thing. However, the council was concerned that the committee neither had the skill set needed nor that this view was representative of other locals.

Despite the imminent passing of responsibility from the local authority to other organisations, the council was dutybound to ensure what resulted from the process was effective and would benefit the wider community. For the council, the project could only be successful if run by a likeminded professional organisation, rather than a group of residents who may be willing, but who lacked the skill set required. Within the process, the notion of professionalism framed what was expected and ensure the commissioned intervention was similar to the council's own services. (Brubaker and Keegan 2018; Evetts 2006, 2011a, 2013; Waring and Waring 2009).

To cut short discussions about the residents' role, it was agreed that the committee could apply for the funding alongside Saplings. The residents' proposal stressed the importance of their locally informed relational approach. In contrast, Saplings produced a well structured, budgeted proposal that focused on the intervention being delivered by trained professionals.

The difference in approach between the two groups is exemplified in the staffing section of each proposal, an excerpt of which is included in the table below:

\begin{tabular}{|c|c|}
\hline Residents Committee Proposal & Saplings Proposal \\
\hline $\begin{array}{l}\text { Wages for Charis: Charis was doing a huge amount } \\
\text { of work on the understanding that she would never } \\
\text { be paid... [however] the responsibility and the time } \\
\text { taken to do a good job had grown... Without Charis, } \\
\text { there is no project. Her position as the person who } \\
\text { knows all the young people individually as well as } \\
\text { many of their parents is incredibly important. She } \\
\text { has said that she will visit the parents of any young } \\
\text { person who becomes part of the group. She is totally } \\
\text { dedicated to the young people. } \\
\text { I suggest: - } 16 \text { hours a week } x 10 \text { an hour = } 160 \text { a } \\
\text { week } x 52=£ 8,320 \\
\text { For that we have the best worker - she would } \\
\text { function pretty much full time. She could do } 3 \\
\text { sessions a week of } 5.30-9.30 \\
\text { (Taken from the Residents' Committee's proposal to } \\
\text { run the co-produced youth service). }\end{array}$ & $\begin{array}{l}2 \text { weekly sessions for } 8 \text { to } 13 \text { year olds - Youth club- } \\
\text { type activities and music, media, art, sport based } \\
\text { activities with personal development embedded. } \\
2 \text { weekly sessions for } 14 \text { to } 19 \text { year olds -- Youth } \\
\text { club-type activities and music, media, art, sport } \\
\text { based activities with personal development } \\
\text { embedded. } \\
\text { See separate budget sheet attached } \\
\text { (Taken from the Saplings' proposal to run the co- } \\
\text { produced youth service). }\end{array}$ \\
\hline
\end{tabular}

The desire to show their local connection and care for the young people, the residents' missed the opportunity to show they knew the rules and habitus of the professional field and confirmed the council's belief that they were 
incapable of being commissioned. The committee contained an accountant, a retired social worker, and a project manager. However, interacting with friends to support people they cared about, led to an informal field being established, developed out of residents' everyday interactions. In this field, the more care and support someone offered, the more respected they were. People such as Charis and Elizabeth had top status because of the number of people they knew and the care and concern they had shown over a long time. They believed their habitus and relational capital would have value when collaborating with those from a professional field; it didn't. Their approach led to Darren at a subsequent meeting to state:

"Well, you have read it, you can see why it can't be accepted, I mean it just can't be."

(Field Note Journal 27/11/11)

The Saplings proposal was weighted in the opposite direction, setting out a structure for the weekly sessions. Its budget looked far more thought through and was professionally presented in a format that the council recognized as operational.

Once the project started, the council (as seen in the excerpt below) was keen for the St Mary's Network to manage the project, ensuring local people were empowered and the project met the local need:

"We also discussed that I would like all major changes to the project and progress reports to go to the Network for approval in the first instance rather than to me as contract manager as I think this is a better way of ensuring activity is adapted dependent on local need."

(Email from the Youth Service Contracts Manager 01/02/12)

However, the process further disempowered residents. The local network only had two residents as its members but included directors and staff of three local organisations. The act of taking the project's management out of the hands of the local authority and giving it to the new representative body placed the residents as two of many stakeholders, most of whom had no intrinsic connection to the estate. The importance of the network in the cooperative council structure legitimised this disempowering of the residents and the preferencing of the local professional voices. The residents committee requested that any proposed changes to the commissioned youth project be discussed at their meetings first. However, when the oversight was given to the network, they decided the project should be overseen by their youth subgroup, which would include representatives of the residents 
committee and Saplings. The formalized process and the fact that residents were outnumbered left the residents with little influence.

This disempowerment resulted in the Residents Committee's secretary and originator of the initial youth work on the estate to send an email to [Author] before the second subgroup meeting stating:

Wonder if you are free to go to this? I'd normally go but - never again! Last night was a disaster - be ready for tonight - REALLY important to be ready to a) vote Charis as caretaker and b) vote for keyholders to be the only people with external keys (i.e. no groups to have personal access)

(Email from Elizabeth 02/05/12)

After 6 years of trying to support young people and years of being a go to person on the estate, Elizabeth's first experience of the subgroup left her withdrawing and seeing the only way to retain some power was to vote in a (resident) caretaker who would hold the keys to the building.

\section{Discussion}

\section{Clarity Matters}

Although the activities on the estate were based on the council's co-operative stance, there was very little understanding of what this meant in practice. This is evident, not only in the Deputy Director's statement of not really knowing what the change meant but also in what took place. There was a concerted effort on the part of the council to engage more residents, with the commissioning of specialists to develop resident led projects on the estate. Yet although the involvement of professionals is a key component in successful co-productive projects (Fledderus et al., 2015; Innes et al., 2018; Vanleene, et al., 2018), the interventions were prescriptive with pre developed ways to get involved and lacking a bottom up empowering approach (Tonkens and Verhoeven, 2018; Vanleene et al., 2019). With the lack of understanding of what a co-productive process entailed, the activities were developed to fit within the council's staffs existing frame of reference, mirroring their existing structures. In effect, rather than being co-productive and empowering, the power just shifted from one set of professionals to another. Once the commissioned youth project started, its governance took the form of formal meetings, meaning that only those who were used to professional environments would be comfortable engaging (Fung, 2015), and leading to an under representation of estate residents (Tonkens and Verhoeven, 2018). Processes that were meant inclusive, because of the prioritising of professional input, reinforced exclusivity (Crompton, 2018; Jakobsen and 
Andersen 2013; Thijssen and Van Dooren 2015) This resulted in the resident's voice being simply part of the bureaucratic process (Boswell and Corbett, 2017, Crompton, 2018), remaining marginal rather than becoming intrinsic (Leyshon, Leyshon and Jeffries, 2018).

\section{Recognising the power of social fields}

Throughout the process, the council framed the engagement to prioritise professionalism and the residents were expected to engage accordingly (Fledderus, Brandsen, and Honingh, 2015; Pestoff and Brandsen, 2010). In effect, the council inserted their field, complete with its valuation of different forms of capital and habitus, onto the estate. In this field, professional skills, professional connections, qualifications and as so acted as symbolic capital that indicated the capability to deliver effectively. This was seen as giving more assurances than the relational approach of the residents (Mckenzie, 2015). The need to regulate the outcome (Innes et al., 2018) led to the council taking the default position of relying on notions of professionalism rather than participatory collaboration. The local people that the council wanted to engage and hand responsibility over to were not ordinary residents, but likeminded professionals. Residents could engage, but only in the way prescribed by the council and their preferred service deliverers. There was no reciprocal understanding of how the professionals involved may need to adapt their practices to accommodate and empower the residents (Booth 2019; Farr 2018). As such, professional and lay expertise (Kotzee, 2014) were only notionally placed alongside each other and the co-productive efforts failed to move past the existing unhelpful dichotic service provider, service user power structures. (Booth 2019; Farr 2018). The efforts to co-commission had placed the residents into a professional field (Bourdieu, 1984) where the habitus of the professionals engaged was misrecognised as natural (Bottero 2010; Decoteau 2015; Oliver and O’Reilly 2010; Steinmetz 2011). The need to officialise acted as a form of domination (Bourdieu, 1972), making the relational informal habitus of the residents appear inferior (Mckenzie, 2015) and causing them to have to engage in a way they were not used to.

The lack of understanding concerning the different social fields that the potential co-producers operated within resulted in a replication of the existing professional structures. This is despite the local authority admitting they were not the most effective way to deliver services. Not only were the structures reproduced, so was the hierarchical dynamic, which left residents disempowered. 


\section{Valuing and Incorporating Difference}

Within this co-commissioning, the hierarchical professional power dynamics defined the parameters of engagement (McQuaid 2010). Although this allowed the council to control a space it was vacating, it restricted the collaborative potential. Professionalism was a symbolic capital (Bourdieu 1990) that legitimised Saplings' pre-selected position and the preclusion of residents (Evetts 2003, 2006, 2011, 2013). Those leading the project defaulted back to operating in a way that saw the residents as people who needed a service being provided for them, with participation largely tokenistic (Arnstein, 2008, Crompton, 2018, McQuaid, 2010) initially to meet, even if symbolically, the ideals of the co-operative council. The lack of appreciation not only of the residents as experts in their field (Kotzee, 2012) but of this type of expertise altogether, resulted in power being retained by those considered professional. Instead of being empowered, the residents saw the power to shape what happened on their estate transfer from the local authority to an organisation chosen to act in their stead.

Failing to recognise the value of a different approach, both in terms of delivering to young people and in the project's oversight, meant that any potential benefit of incorporating a more informal approach was lost. For the project to benefit from a co-productive process, there needed to be a placing of the residents' voices alongside the professionals (Booth 2019; Bovaird, et al., 2015; Crompton; 2018; Flinders and Wood, 2018; Pestoff 2009; Vanleene, et al., 2018). Yet instead of the creation of collective goals (Alford and Yates, 2016), the process largely resulted in a surface level legitimising of the council's aim of outsourcing a local youth intervention project to an already established council service provider.

\section{Conclusion}

Co-production poses the opportunity to involve people from more diverse backgrounds and experiences in the delivery of local services. The analysis above shows that unless issues related to unequal power dynamics are addressed, the empowerment associated with co-productive participation will not be realised. One hindrance to this happening is how people can revert to what is normal within their own social field as a way of ensuring projects are effective, with those within the most powerful social field dominating what this looks like. In the study above, not only did this result in the council commissioning an organisation that it felt would deliver along the same lines as it used to, but it also meant that the management of the subsequent project followed formal principles that were disempowering to residents. 
When attempting to co-produce in deprived neighbourhoods, the study would suggest that the following are key principles for practitioners: 1) Ensure that there is clarity about the core values guiding co-production. At a surface level, the project described above was a success in that the council was able to commission a local organization to deliver youth interventions on a local estate. However, just because residents were in the room, doesn't make the process co-productive. Although the new council constitution highlighted the need to do things with, rather than to, local people, there was no indication of what this meant and as a result. Whilst the process spoke about giving local people more control, those who were meant to be most empowered, ended up disenfranchised. Clearer guidance on what co-production needed to involve alongside a stronger committal to the process, rather than seeing the process as a means to an end, may have prevented this. 2) Practitioners should not default into replicating established processes and procedures, as these are likely to also reproduce the hierarchical and disempowering dynamics that prevent effective co-production, and lead to one group or practice dominating others. 3) Be reflexive in relation to distinctions and preferences. Co-production draws seeks to find more effective and efficient ways of addressing issues through bringing together people from different professions as well as those to whom professional practices may be alien. Those involved in collaborative working are likely to usually operate in very different social fields to one another. These social fields can determine people's outlook on what success, and the most effective way to achieve this success, looks like. Preferencing one such social field over another will lead to a power imbalance, disenfranchise those whose habitus is considered inferior and diminish the co-productive potential. The process of co-production should take into account how the different groups involved usually interact and value each approach equally.

With co-production continuing to be en vogue as a way to ensure public value through developing citizen empowerment: and efficient and innovative ways to provide public services, further study would be advisable to understand if 'collaborative' projects between professionals and residents of other deprived neighbourhoods experience the same issues. This would help to further develop a comprehensive understanding of how best to ensure the benefits of co-production can be realised.

\section{Data Availability statement}

The data that support the findings of this study are available on request from the author. The data are not publicly available due to their containing information that could compromise the privacy of research participants.

\section{Conflict of interest disclosure}

The author knows of no conflicts of interest related to this submission 


\section{Bibliography}

Adler P, Adler P (1987) Membership Roles in Field Research. London. Sage

https://doi.org/10.4135/9781412984973

Alford J (2013).Engaging Citizens in Co-producing Service Outcomes. In E. A. Lindquist, S. Vincent, \& J. Wanna (Eds.), Putting Citizens First (pp. 75-82). Camberra. ANU Press

Alford J, Yates S (2016) Co-Production of Public Services in Australia: The Roles of Government Organisations and Co-Producers. Australian Journal of Public Administration, 75(2), 159-175. https://doi.org/10.1111/1467-8500.12157

Amit V (2004) Constructing the field: Ethnographic fieldwork in the contemporary world. London. Routledge.

Anderson L (2006) Analytic Autoethnography. Journal of Contemporary Ethnography, 35(4), 373-395. https://doi.org/10.1177/0891241605280449

Andreassen T, Breit E, Legard S (2014) The making of 'professional amateurs': Professionalizing the voluntary work of service user representatives. Acta Sociologica, 57(4), 325-340. https://doi.org/10.1177/0001699314552736

Ashcraft K, Muhr S, Rennstam J, Sullivan, K (2012) Professionalization as a Branding Activity: Occupational Identity and the Dialectic of Inclusivity-Exclusivity. Gender, Work \& Organization, 19(5), $467-488$.

Blackman S (2007) ‘Hidden Ethnography’: Crossing Emotional Borders in Qualitative Accounts of Young People's Lives. Sociology, 41(4), 699-716. https://doi.org/10.1177/0038038507078925

Booth J (2019) Empowering Disadvantaged Communities in the UK: Missing the Potential of Coproduction. Social Change, 49(2), 276-292. https://doi.org/10.1177/0049085719832401

Bottero W (2010) Intersubjectivity and Bourdieusian Approaches to 'Identity'. Cultural Sociology, 4(1), 322. https://doi.org/10.1177/1749975509356750 
Bourdieu P (1977) Outline of a theory of practice. Cambridge. Cambridge University Press

Bourdieu P (2002) Masculine Domination. Stanford. Stanford University Press

Bourdieu, P (1984) Distinction: A social critique of the judgement of taste. London. Routledge \& Kegan Paul

Bourdieu, Pierre. (2014) The Logic Of Practice. Oxford. Polity Press

Bovaird, T, Loeffler E (2012) From Engagement to Co-production: The Contribution of Users and Communities to Outcomes and Public Value. Voluntas: International Journal of Voluntary \& Nonprofit Organizations, 23(4), 1119-1138

Bovaird T, Stoker G, Jones T, Loeffler E, Pinilla Roncancio M (2015) Activating collective co-production of public services: Influencing citizens to participate in complex governance mechanisms in the UK. International Review of Administrative Sciences, 82(1), 47-68. https://doi.org/10.1177/0020852314566009

Bovaird T, Van Ryzin G, Loeffler E, Parrado S (2015) Activating Citizens to Participate in Collective CoProduction of Public Services. Journal of Social Policy, 44(1), 1-23.

https://doi.org/10.1017/S0047279414000567

Brandsen T, Honingh M (2016) Distinguishing Different Types of Co-production: A Conceptual Analysis Based on the Classical Definitions. Public Administration Review, 76(3), 427-435.

https://doi.org/10.1111/puar.12465

Brubaker S, Keegan B (2018) “Suddenly Everyone’s an Expert in Our Field”: Campus Victim Advocates and the Promise and Perils of Professionalization. Violence Against Women, 25(9), 1116-1137. https://doi.org/10.1177/1077801218807096

Brunton-Smith I, Bullock K (2019) Patterns and Drivers of Co-production in Neighbourhood Watch in England and Wales: From Neo-liberalism to New Localism. British Journal of Criminology, 59(1), 85-106

Bucerius S (2013) Becoming a "Trusted Outsider": Gender, Ethnicity, and Inequality in Ethnographic Research. Journal of Contemporary Ethnography, 42(6), 690-721.

https://doi.org/10.1177/0891241613497747 
Charmaz K (2004) Premises, Principles, and Practices in Qualitative Research: Revisiting the Foundations.

Qualitative Health Research, 14(7), 976-993. https://doi.org/10.1177/1049732304266795

Crompton A (2019) Inside co-production: Stakeholder meaning and situated practice. Social Policy \& Administration, 53(2), 219-232.

Decoteau C (2015) The reflexive habitus: Critical realist and Bourdieusian social action. European Journal of Social Theory, 19(3), 303-321. https://doi.org/10.1177/1368431015590700

Denshire S (2014) On auto-ethnography. Current Sociology, 62(6), 831-850.

https://doi.org/10.1177/0011392114533339

Denzin N, Lincoln Y (2018) The Sage handbook of qualitative research. London. Sage.

Dhattiwala R (2017) Mapping the self: Challenges of insider research in a riot-affected city and strategies to improve data quality. Contemporary South Asia, 25(1), 7-22.

https://doi.org/10.1080/09584935.2017.1297385

Docherty I, Goodlad R, Paddison R (2001) Civic Culture, Community and Citizen Participation in Contrasting Neighbourhoods. Urban Studies, 38(12), 2225-2250.

https://doi.org/10.1080/00420980120087144

Dwyer S, Buckle, J (2009) The Space Between: On Being an Insider-Outsider in Qualitative Research. International Journal of Qualitative Methods, 8(1), 54-63

Eglinton K (2013) Youth identities, localities, and visual material culture: Making selves, making worlds. London. Springer

Emmel N (2018) Sampling and Choosing Cases in Qualitative Research: A Realist Approach. Sage Research Methods https://doi.org/10.4135/9781473913882

Evetts J (2006) Trust and Professionalism: Challenges and Occupational Changes. Current Sociology, 54(4), 515-531

Evetts J (2009) New Professionalism and New Public Management: Changes, Continuities and Consequences. Comparative Sociology, 8(2), 247-266 
Evetts, J. (2013). Professionalism: Value and ideology. Current Sociology, 61(5/6), 778-796

Farr M (2017) Power dynamics and collaborative mechanisms in co-production and co-design processes. Critical Social Policy, 38(4), 623-644. https://doi.org/10.1177/0261018317747444

Flinders M, Wood M (2019) Ethnographic insights into competing forms of co-production: A case study of the politics of street trees in a northern English city. Social Policy \& Administration, 53(2), 279-294

Fung A (2015) Putting the Public Back into Governance: The Challenges of Citizen Participation and Its Future. Public Administration Review, 75(4), 513-522. https://doi.org/10.1111/puar.12361

Galuszka J (2018) What makes urban governance co-productive? Contradictions in the current debate on co-production. Planning Theory, 18(1), 143-160. https://doi.org/10.1177/1473095218780535

Geertz C (2007) Works and lives: The anthropologist as author. Oxford. Polity Press.

Corbin J, Strauss A (2008) Theoretical sampling. In Corbin, J., \& Strauss, A. Basics of qualitative research (3rd ed.): Techniques and procedures for developing grounded theory (pp. 143-158). Thousand Oaks, CA: SAGE Publications, doi: 10.4135/9781452230153

Gobo G (2018) Doing Ethnography. London. Sage. https://doi.org/10.4135/9780857028976

Hammersley M, Atkinson P (2010) Ethnography: Principles in Practice. London. Routledge.

Hickman P (2018) A Flawed Construct? Understanding and Unpicking the Concept of Resilience in the Context of Economic Hardship. Social Policy and Society, 17(3), 409-424. Cambridge Core. https://doi.org/10.1017/S1474746417000227

Innes M, Davies B, McDermont M (2018) How Co-Production Regulates. Social \& Legal Studies, 28(3), 370-391. https://doi.org/10.1177/0964663918777803

Jakobsen M, Andersen S (2013) Co-production and Equity in Public Service Delivery. Public Administration Review, 73(5), 704-713. https://doi.org/10.1111/puar.12094

James E (2016) The professional humanitarian and the downsides of professionalisation. Disasters, 40(2), $185-206$ 
Karner A, Brower Brown K, Marcantonio R, Alcorn L (2019) The View From the Top of Arnstein's

Ladder. Journal of the American Planning Association, 85(3), 236-254.

https://doi.org/10.1080/01944363.2019.1617767

Kotzee B (2014) Expertise, fluency and social realism about professional knowledge. Journal of Education and Work, 27(2), 161-178. https://doi.org/10.1080/13639080.2012.738291

Leyshon C, Leyshon M, Jeffries J (2019) The complex spaces of co-production, volunteering, ageing and care. Area, 51(3), 433-442.

Loeffler E, Bovaird T (2019) Co-commissioning of public services and outcomes in the UK: Bringing coproduction into the strategic commissioning cycle. Public Money \& Management, 39(4), 241-252. https://doi.org/10.1080/09540962.2019.1592905

Lyons M (2011) The Professionalization of Children's Services in Australia. Journal of Sociology, 48(2), 115-131. https://doi.org/10.1177/1440783311407945

Machamer P, Darden L, Craver C (2000) Thinking about Mechanisms. Philosophy of Science, 67(1), 1-25. https://doi.org/10.1086/392759

Mathers J, Parry J, Jones S (2008) Exploring Resident (Non-)participation in the UK New Deal for Communities Regeneration Programme. Urban Studies, 45(3), 591-606.

https://doi.org/10.1177/0042098007087336

McKenzie L (2013) Narratives from a Nottingham council estate: A story of white working-class mothers with mixed-race children. Ethnic and Racial Studies, 36(8), 1342-1358.

https://doi.org/10.1080/01419870.2013.776698

Mckenzie Lisa (2015) Getting by: Estates, class and culture in austerity Britain. Bristol Policy Press

Molland S (2013) Tandem ethnography: On researching 'trafficking' and 'anti-trafficking'. Ethnography, 14(3), 300-323. https://doi.org/10.1177/1466138113491671

Moskovskaia A (2012) The Professionalization of Management. Russian Education \& Society, 54(3), 2242 
Noordegraaf M (2011. Remaking professionals? How associations and professional education connect professionalism and organizations. Current Sociology, 59(4), 465-488.

https://doi.org/10.1177/0011392111402716

Offer S (2012) The burden of reciprocity: Processes of exclusion and withdrawal from personal networks among low-income families. Current Sociology, 60(6), 788-805.

https://doi.org/10.1177/0011392112454754

Oliver C, O’Reilly K (2010) A Bourdieusian Analysis of Class and Migration: Habitus and the Individualizing Process. Sociology, 44(1), 49-66. https://doi.org/10.1177/0038038509351627

Osborne S (2010) The New Public Governance? : Emerging Perspectives on the Theory and Practice of Public Governance. London. Routledge

Pemberton S, Fahmy E, Sutton E, Bell K (2015) Navigating the stigmatised identities of poverty in austere times: Resisting and responding to narratives of personal failure. Critical Social Policy, 36(1), 21-37. https://doi.org/10.1177/0261018315601799

Pestoff V (2012) Co-production and Third Sector Social Services in Europe: Some Concepts and Evidence. Voluntas: International Journal of Voluntary \& Nonprofit Organizations, 23(4), 1102-1118

Pestoff V, Brandsen T (2010) Public governance and the third sector: Opportunities for co-production and innovation in Osborne, S.P. (ed.), The New Public Governance: Emerging Perspectives on the Theory and Practice of Public Governance. London. Routledge pp. 223-236

Steinmetz G (2011) Bourdieu, Historicity, and Historical Sociology. Cultural Sociology, 5(1), 45-66

Swartz D (2013) Symbolic power, politics, and intellectuals: The political sociology of Pierre Bourdieu.

Chicago. University of Chicago Press

Tavory I, Timmermans, S (2013) A Pragmatist Approach to Causality in Ethnography. American Journal of Sociology, 119(3), 682-714. https://doi.org/10.1086/675891

Thijssen P, Van Dooren W (2015) Who you are/where you live: Do neighbourhood characteristics explain co-production? International Review of Administrative Sciences, 82(1), 88-109. 
https://doi.org/10.1177/0020852315570554

Tonkens E, Verhoeven I (2018) The civic support paradox: Fighting unequal participation in deprived neighbourhoods. Urban Studies, 56(8), 1595-1610. https://doi.org/10.1177/0042098018761536

van Eijk C (2018) Helping Dutch Neighborhood Watch Schemes to Survive the Rainy Season: Studying Mutual Perceptions on Citizens' and Professionals' Engagement in the Co-Production of Community Safety. Voluntas: International Journal of Voluntary \& Nonprofit Organizations, 29(1), 222-236

van Eijk C, Steen T (2015) Why engage in co-production of public services? Mixing theory and empirical evidence. International Review of Administrative Sciences, 82(1), 28-46.

https://doi.org/10.1177/0020852314566007

Vanleene D, Voets J, Verschuere B (2018) The Co-production of a Community: Engaging Citizens in Derelict Neighbourhoods. Voluntas: International Journal of Voluntary \& Nonprofit Organizations, 29(1), $201-221$

Vanleene D, Voets J, Verschuere B (2019) The co-production of public value in community development: Can street-level professionals make a difference? International Review of Administrative Sciences, https://doi.org/10.1177/0020852318804040 